\title{
Use of conditioning in the production of black and white oat hay using two cutting heights
}

\section{Deise Dalazen Castagnara ${ }^{1}$, Marcela Abbado Neres $^{1}$, Paulo Sérgio Rabello de Oliveira ${ }^{1}$, Cristiane Claudia Meinerz ${ }^{1}$, Eduardo Eustáquio Mesquita ${ }^{1}$}

1 Universidade Estadual do Oeste do Paraná - Unioeste. Rua Pernambuco, 1777. Centro, Marechal Cândido Rondon - PR. 85960-000.

\begin{abstract}
The study was conducted to estimate the dehydration curves, chemical composition, and occurrence of fungi in white oat hay (Avena sativa L. cv. Guapa BRS) and black oat hay (Avena strigosa Schreb cv. Common) at two cutting heights. Dehydration curves were studied under a randomized block design with a $2 \times 2$ factorial arrangement using split plots in time, considering two types of oats (white and black), two cutting heights (10 and $20 \mathrm{~cm}$ ), and 17 sampling times (0, 4, 19, 24, 28, 43, 47, 52, 67, 71, 76, 91, 95, 100, 115, 129, and 124 hours after harvesting) with five replicates. For the chemical composition and occurrence of fungi, the experimental design comprised randomized blocks in a factorial $2 \times 2$ split-plot in time with two types of oats, two cutting heights, and three assessment periods: before cutting, during baling, and after 30 days of storage, with five replicates. The hay obtained by cutting of the black and white oats at heights of 10 and $20 \mathrm{~cm}$ showed similar dehydration curves. The crude protein values were higher in white oats only at the time of cutting $(141.5 \mathrm{~g} / \mathrm{kg})$. The black oats showed lower nutritional quality, with higher levels of ADF and lignin. There was no effect of cutting height on the chemical composition, but the cutting height interfered with the production of dry matter and residue after cutting, with cutting at $10 \mathrm{~cm}$ leading to higher dry matter production and at $20 \mathrm{~cm}$ to increased waste production. The cutting heights of the oats interfere directly with the dry matter production and post-harvest residue without changing the chemical composition of the hay.
\end{abstract}

Key Words: Avena spp., crude protein, dehydration curves, storage fungi, straw

\section{Introduction}

Oats are an alternative winter crop used in South Brazil mainly for the production of forage and grain and as a green cover. Some cultivars of white oats (Avena sativa L.) have dual purposes, while black oats (Avena strigosa Schreb) are typically used as forage (Floss et al., 2007), which highlights the importance of dry matter yield for the formation of straw (Floss, 2002).

Due to the wide use of agricultural land for grains in the summer in western Paraná, the use of oats emerged as a viable alternative to crop-livestock integration. The cultivation of oats during the winter makes it possible to obtain high-quality forage and straw to cover the soil for the sowing of summer crops in no-tillage system.

However, the amount of residual straw cover and forage quality obtained are dependent on the management applied to the culture. The residual amount of straw increases proportionally with the cutting height adopted. However, the quality of conserved forage changes due to the procedures adopted for its production and conservation and microbiological and chemical phenomena that occur in the process (Jobim et al., 2007).

Mowing conditioners cause injuries and accelerate the drying rate in plants, especially in the stems. Injuries cause the dehydration rate to accelerate, reducing the drying time and risk of losses due to rainfall, but may, however, change the nutritional value of the conserved forage.

Along with handling, storage conditions directly affect the chemical and microbiological quality of the hay, as well as losses during storage (Domingues, 2009).

In this sense, the objective of this study was to evaluate the structural characteristics and production, residual straw, dehydration curves, chemical composition, and occurrence of fungi in the fresh forage and hay obtained from black and white oats using two cutting heights.

\section{Material and Methods}

The experiment was conducted under field conditions at the Experimental Farm Antônio Carlos dos Santos Pessoa belonging to the State University of West Paraná, 
Marechal Cândido Rondon campus, located at coordinates $24^{\circ} 33^{\prime} 40^{\prime \prime} \mathrm{S}$ latitude, $54^{\circ}$ 04' $12^{\prime \prime} \mathrm{W}$ longitude and $420 \mathrm{~m}$ altitude. The local climate is classified according to Köppen as Cfa type, subtropical with rainfall, which is well distributed during the year and hot summers. The average temperatures vary between 17 and $18{ }^{\circ} \mathrm{C}$ during the coldest quarter, between 28 and $29{ }^{\circ} \mathrm{C}$ during the warmest quarter, and between 22 and $23{ }^{\circ} \mathrm{C}$ yearly. The total average annual regular rainfall for the region ranges from 1600 to $1800 \mathrm{~mm}$, with the wettest quarter showing a total ranging from 400 to $500 \mathrm{~mm}$ (IAPAR, 2006). During plant growth, there was a period of drought (Figure 1), while during dehydration, climatic conditions were favorable (Table 1 ).

The soil of the experimental area is classified as Oxisol (EMBRAPA, 2006) and has the following chemical characteristics: $\mathrm{pH}$ in water $=5.20 ; \mathrm{P}($ Mehlich $)=13.59 \mathrm{mg} /$ $\mathrm{dm}^{3} ; \mathrm{K}($ Mehlich $)=0.32 \mathrm{cmol}_{\mathrm{c}} / \mathrm{dm}^{3} ; \mathrm{Ca}^{2+}(\mathrm{KCl} 1 \mathrm{~mol} / \mathrm{L})=$ $3.17 \mathrm{cmol}_{\mathrm{C}} / \mathrm{dm}^{3} ; \mathrm{Mg}^{2+}(\mathrm{KCl} 1 \mathrm{~mol} / \mathrm{L})=1.77 \mathrm{cmol}_{\mathrm{c}} / \mathrm{dm}^{3}$;

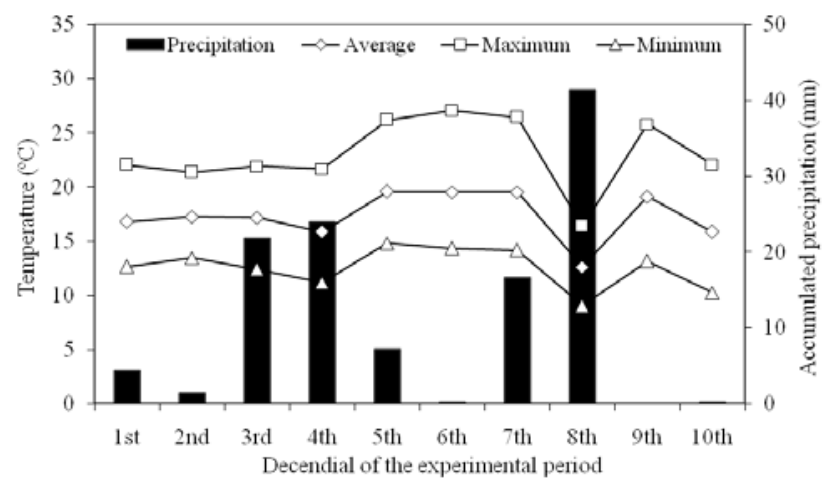

Figure 1 - Climate data during the experiment (Marechal Cândido Rondon, May-August 2010).
$\mathrm{Al}^{3}+(\mathrm{KCl} 1 \mathrm{~mol} / \mathrm{L})=0.20 \mathrm{cmolc} / \mathrm{dm}^{3} ; \mathrm{H}+\mathrm{Al}$ (calcium acetate $0.5 \mathrm{~mol} / \mathrm{L})=4.96 \mathrm{cmol}_{c} / \mathrm{dm}^{3} ;$ sum of bases $=5.26 \mathrm{cmol}_{\mathrm{c}} / \mathrm{dm}^{3}$; CTC $=10.22 \mathrm{cmol}_{\mathrm{c}} / \mathrm{dm}^{3} ; \mathrm{V}=51.47 \%$, organic matter (Boyocus Method) $=25.29 \mathrm{~g} / \mathrm{dm}^{3}$; and clay $=65 \%$.

Black oat cv. Common and white oat line UFRGS 998011-2 Guapa were used. The forage sowing was performed in $0.17 \mathrm{~m}$ spaced rows with a precision seed drill pulled by a tractor on May 4, 2010. Seventy and $60 \mathrm{~kg} / \mathrm{ha}$ of white and black oat seeds, respectively, and $250 \mathrm{~kg} / \mathrm{ha}$ of formulated 2-20-15 $\left(\mathrm{N}-\mathrm{P}_{2} \mathrm{O}_{5}-\mathrm{K}_{2} \mathrm{O}\right)$ were used at sowing.

The oats were cut at 13:00 h on August 6, 2010 using a beater mower conditioner with free fingers (KUHN brand). Due to conditioning, no turning took place during the dehydration. The stage recommended for cutting oats for hay is full bloom (CBPA, 2006); however, due to the unfavourable weather conditions, there was a delay in cutting fodder, and when the plants were cut the white oats were at the dough grain stage while the black oat plants were at the milky grain stage. The differences observed in phenological stages are due to the cycles of different cultures, since UFRGS Guapa oats have an early cycle (up to 80 days) (CBPA, 2006), while the cycle of black oats can exceed 135 days (Schuch et al., 2000).

To control the local effect, oats and cutting heights were distributed under a randomized blocks design in a $2 \times 2$ factorial arrangement with five replicates, totalling 20 plots with an area of $5 \times 10 \mathrm{~m}$ each. To determine the dehydration curves, an experimental design of randomized blocks in a $2 \times 2$ factorial arrangement with a split plot in time (17), two types of oats (white and black), two cutting heights (10 and $20 \mathrm{~cm}$ ), and 17 sampling times $(0,4,19,24$, $28,43,47,52,67,71,76,91,95,100,115,119$, and 124 hours after harvest) with five replicates were used. The collection

Table 1 - Climate data on the dates for the cutting and drying of oat plants (Marechal Cândido Rondon, March 2010)

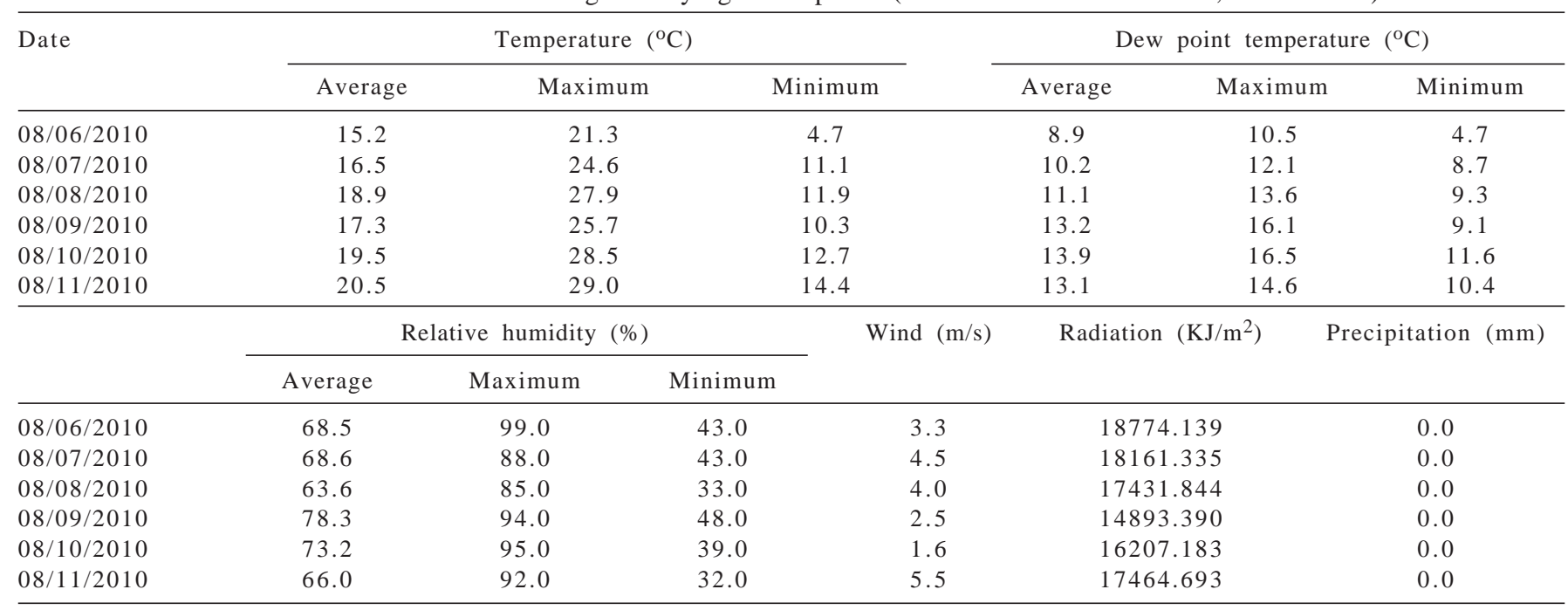


times corresponded to the following times: cutting day: (0) 13:00, (4) 17:00; second day: (19) 8:00, (24) 12:00, (28) 17:00; third day: (43) 8:00, (47) 12:00, (52) 17:00; fourth day: (67) 8:00, (71) 12:00, (76) 17:00; fifth day: (91) 8:00, (95) 12:00, (100) 17:00; sixth day: (115) 8:00, (119) 12:00, (124) 16:00.

The productive and structural characteristics of the forage subjected to dehydration were studied according to a randomized block design in a $2 \times 2$ factorial arrangement with two types of oats (white and black), two cutting heights (10 and $20 \mathrm{~cm}$ ), and five repetitions. For the chemical composition and occurrence of fungi, the experimental design comprised randomized blocks in a $2 \times 2$ factorial split-plot in time (3) with two types of oats (white and black), two cutting heights (10 and $20 \mathrm{~cm}$ ), and three assessment periods (before cutting, at the time of baling, and after 30 days of storage), with five replicates.

Plant height was considered as the distance between ground level and the apex of the panicle and was determined using a scale graduated in centimetres at three points in each plot. The stem diameter was obtained with the aid of digital calipers on the basis of 10 randomly selected tillers in each plot. The tiller count was performed with a $0.25 \mathrm{~m}^{2}$ square thrown randomly with five replicates per plot. Sampling was conducted with a $1.0 \mathrm{~m}^{2}$ square thrown randomly on each plot before the passage of the mower. Samples were separated into three subsamples, of which the first was designed to evaluate the chemical composition, the second was separated into leaves (leaf blades), stems (stems plus sheaths), and panicles, and the third was aimed at assessing the occurrence of fungi. The first and second sub-samples were packed in paper bags, weighed, placed in a forced-ventilation oven, and maintained at $55^{\circ} \mathrm{C}$ for 72 hours for drying. After drying, samples were weighed, and from the data obtained, the leaf/stem ratio, dry matter (DM) content, and proportion of each fraction (leaf, stem, and panicle) in forage plants were calculated. To determine the amount of waste, a new sampling was performed after baling by cutting the plants at the soil surface level with a $1.0 \mathrm{~m}^{2}$ square thrown randomly on each plot followed by drying of samples in forced ventilation oven at $55^{\circ} \mathrm{C}$ for 72 hours.

The dehydration curves were estimated by determining the dry matter of 300 g samples collected from each plot according to established times. After 124 hours of dehydration, another sampling was conducted to determine the chemical composition and occurrence of fungi with subsequent bundling. When the hay had approximately $800 \mathrm{mg} / \mathrm{kg}$ of dry matter, it was mechanically baled in rectangular bales with an average weight of $12 \mathrm{~kg}$ and stored in a barn, protected from rain and sunshine, and under identical conditions of temperature, light and moisture. After the storage time (30 days), bales were opened for further sampling.

After drying, samples for evaluating the chemical composition were ground in a Wiley type mill with a 30 mesh sieve and subjected to laboratory procedures for determination of crude protein (CP) according to the AOAC (1990), neutral detergent fiber (NDF) and acid detergent fiber (ADF) according to Van Soest et al. (1991), and neutral detergent insoluble protein (NDIP, expressed in g/kg of CP), acid detergent insoluble protein (ADIP, expressed in $\mathrm{g} / \mathrm{kg}$ of $\mathrm{CP}$ ), lignin, hemicellulose, and cellulose according to Silva \& Queiroz (2006).

Fungi were quantified in PDA culture medium (200 g potato, 20 g dextrose, $15 \mathrm{~g}$ agar, and $1000 \mathrm{~mL}$ distilled water) through dilutions in sterile distilled water from the samples collected (Fernandez, 1993). For identification of fungal colonies, specific identification keys (Barnett \& Hunter, 1987; Carmichael et al., 1980) were used.

Data on dry matter according to time of dehydration were submitted to regression analysis to obtain the dehydration curves. Data on structural features, quantification of fungi, dry matter production, and chemical composition were subjected to analysis of variance using the program SAEG (version 7.0), and means were compared by Tukey test at 5\% probability.

\section{Results and Discussion}

There were differences between oats in terms of structural characteristics $(\mathrm{P}<0.01)$, while the only difference between cutting heights was the number of tillers $(\mathrm{P}<0.01)$ (Table 2). The height and number of tillers of the black oats were greater than those of white oats, while for the diameter of the stem and the leaf/stem ratio, the opposite was the case, with the white oats being superior (Table 2). These results are related to the characteristics of each forage species, as the black oats have greater tillering capacity than the white oats (Fontaneli et al., 2009).

Rossetto \& Nakagawa (2001) observed higher plant height than in the present study in black oats at 90 days of development. Floss et al. (2003) also observed higher plant height in the white oats at 87 days of growth. The differences are due to the soil and climatic conditions, as weather conditions were favorable to plant development throughout the period in the aforementioned studies, while in the present study, the low volume of rainfall during the experimental period limited stretching between nodes, and as a result, the plants did not reach the typical heights of the species. 
Table 2 - Structural characteristics and production of white and black oats subjected to two cutting heights for hay production

\begin{tabular}{|c|c|c|c|c|c|c|}
\hline & Height (cm) & $\mathrm{SD}(\mathrm{mm})$ & $\mathrm{L}: \mathrm{S}$ & Tillers $\left(\mathrm{n}^{\circ} / \mathrm{m}^{2}\right)$ & DM (kg/ha) & Residue (kg/ha) \\
\hline \multicolumn{7}{|c|}{ Oats } \\
\hline White & $69.17 b$ & $4.86 a$ & $0.82 \mathrm{a}$ & $104.92 b$ & $6065 a$ & $890 a$ \\
\hline Significance & 0.0000 & 0.0000 & 0.0000 & 0.0000 & 0.4795 & 0.0005 \\
\hline \multicolumn{7}{|c|}{ Cutting heights } \\
\hline Significance & 0.2286 & 0.0800 & 0.4130 & 0.0017 & 0.2329 & 0.0000 \\
\hline Mean & 85.71 & 3.54 & 0.58 & 119.33 & 5993 & 799 \\
\hline CV (\%) & 8.35 & 16.09 & 18.38 & 6.29 & 13.23 & 12.63 \\
\hline
\end{tabular}

*Values followed by same letter in columns do not differ from each other by Tukey test at 5\% probability.

SD - stem diameter; L:S - leaf: stem ratio; DM - dry matter.

Investigation of stem diameter is important in studies evaluating the dehydration curves of forage, as this feature is directly related to the dehydration rate of the forage. Stems with larger diameters have a greater capacity to retain water and take longer to form dry matter suitable for baling. Jobim et al. (2001) found a negative correlation between stem diameter and dehydration rate in the grass genus Cynodon. Overall, according to Martins et al. (2004), the leaf/stem ratio and the amount of leaves remain constant throughout the oat cycle, with changes in the proportion of stems. In white oats, Floss et al. (2007) found big leaves, with the width and length of the flag leaf of 2.3 and $30.9 \mathrm{~cm}$, respectively, while in black oats, Castagnara et al. (2010) observed leaf/stem ratios below 0.5 by the age of 35 days of regrowth. In the study of Floss et al. (2007), the leaf/stem ratio of the white oats was 0.87 at 84 days, and decreased with increasing growth period. An increased presence of leaves in total DM is desirable, since it is the structural component preferably selected by animals, hence the results in higher DM intake (Confortin et al., 2010).

The higher number of tillers obtained with the lowest cutting height is due to the presence of greater levels of extract in the lower sward, since cutting at $20 \mathrm{~cm}$ height did not include the vegetative tillers that had not yet reached this growth stage. The dry matter production was affected only by cutting height $(\mathrm{P}<0.05)$, with higher production obtained with cutting height of $10 \mathrm{~cm}$. The results can be considered satisfactory, since the black oats, even when grown in unfavorable climatic and soil conditions, or with late growth, present productivity of around $4000 \mathrm{~kg} \mathrm{DM} / \mathrm{ha}$ (Ceretta et al., 2002). Camargo \& Pizza (2007) obtained yields of 3490 and $2580 \mathrm{~kg} \mathrm{DM} / \mathrm{ha}$ of black and white oats, respectively, when there were dry periods during the crop development. Bortolini et al. (2005), studying the forage potential of white oats, obtained a yield of $5500 \mathrm{~kg} D \mathrm{DM} / \mathrm{ha}$ during flowering, while Floss et al. (2003), also studying the production of white oats, obtained $5736 \mathrm{~kg} \mathrm{DM} / \mathrm{ha}$ at 84 days after sowing.

Regarding the amount of residue after cutting, there are differences between the oats and between cutting heights $(\mathrm{P}<0.05)$ (Table 2). The white oats provided a higher amount of residual DM (890 kg/ha) compared with black oats (708 kg/ha). This result is related to the shorter height of oat plants, which contributed to a greater amount of leaf extract in the lower sward which was not collected with the cutting heights studied, contributing to the amount of residual dry matter. Regarding the cutting height, higher residual straw was obtained with the cutting height of $20 \mathrm{~cm}$. This result was expected, since with pasture management at greater heights, the amount of forage to be harvested is lower, with a consequent increase in the residual DM. For example, Lopes et al. (2009) observed a linear increase in the amount of residual straw with increases in grazing height on pasture of oats and ryegrass.

It is essential to maintain minimum quantities of straw on the soil surface and to maintain organic matter stocks. Mulch provides the greatest length of the root system of crops (Sá et al., 2004), a higher rate of water infiltration into the soil (Lanzanova et al., 2007), and increased nutrient cycling (Giacomini et al., 2003). However, the recommended amounts for various regions have wide ranges because the amount of straw is dependent on the interaction of several factors such as species used, handling of dry matter, moisture, aeration, temperature, soil microbiological activity and chemical composition (Primavesi et al., 2002). In croplivestock integration systems, the height of forage management should be adjusted in order to maintain the soil characteristics and ensure the productivity of grain crops grown in succession. 
There was difference in DM content $(\mathrm{P}<0.01)$ between oats for all fractions of plants. White oats had lower DM content in the leaves, stems, panicles and whole plants (Table 3). In the study of production of forage conserved as hay, these results are relevant, since the higher water content in the plant will lead to a longer period of drying to achieve a moisture content of $150 \mathrm{~g} / \mathrm{kg}$, which is recommended for hay storage. A higher DM in forage is beneficial for the dehydration process, but is usually related to the reduction of nutritional value of the forage due to increased lignification of cells and lower digestibility of protein and energy.

The white oats had a higher proportion of components in leaves, panicles, and stems in the smallest proportion of forage produced with both cutting heights (Table 3). This result characterizes white oats as a crop with higher potential for forage use; the greater proportion of components with higher nutritional value provides a forage nutrititional value higher than that of black oats, which had participation of stems (633.1 g/kg of forage). Rosetto \& Nakagawa (2001), studying the development of common black oats, noted that the average number of leaves of the main stem grew until the emergence of the panicle, with a subsequent decrease due to the senescence of older leaves. Floss et al. (2007) found that the amounts of leaf, stem, and panicle were 170,530 , and $300 \mathrm{~g} / \mathrm{kg}$, respectively, after 112 days of growth of oats. Stems represented the largest proportion due to differences in the climatic conditions in which the experiments were conducted. In the present study, the lower proportion of stems found was certainly caused by the limitation imposed on their elongation by adverse weather conditions (Figure 1).

Times, oats, heights and the time $\times$ oats interaction had effect on dehydration curves $(\mathrm{P}<0.01)$. Despite presenting a lower DM content at the time of cutting (Table 3), at the time of baling white oats presented a DM content similar to black oats (Figure 2A). In the unfolding over time, cubic behavior of DM was observed over the period of dehydration of oats (Figure 2A). With regard to the cutting heights over time, the authors obtained data which were analyzed by fitting a polynomial regression to fourth degree (Figure 2B). Reductions in dry matter observed 43, 67, 91, and $115 \mathrm{~h}$ after cutting in relation to previous times are related to the rehydration of the material due to the evening dew, because these times coincided with the samples taken at 08:00. Neres et al. (2010), working on the culture of alfalfa, observed similar behavior in the material under dehydration, with a marked decrease in the DM levels every morning due to overnight dew.

According to Rotz (1995), rehydration of plants with dew is due to absorption of water, and the rate of distribution within the plant is related to characteristics of forage such as cuticle thickness, leaf/stem ratio, and stem diameter and to the management applied during dehydration. The importance of using conditioning to accelerate the dehydration process of forage should be highlighted in this study, and even with the use of equipment, the dehydration period was long in comparison with other studies (Ferrari Júnior et al., 1993; Pinto et al., 2006; Neres et al., 2010). However, Reis et al. (2001) mentioned that there are differences in the drying rates of forage plants even when dried in similar climatic conditions.

Despite the long period of dehydration observed, the duration of dehydration did not exceed seven days, which was cited by Collins (1995) as the timeout for the production of hay suitable for animal consumption. Dehydration of plants in the field for prolonged periods can lead to loss of non-structural carbohydrates due to excessive breathing and loss of leaves.

When one considers the times corresponding to the time of 17:00 on each day of the period of dehydration, there were differences $(\mathrm{P}<0.05)$ between cutting heights only to

Table 3 - Dry matter fractions and proportions of the fodder plants subjected to dehydration

\begin{tabular}{|c|c|c|c|c|c|c|c|}
\hline & \multicolumn{4}{|c|}{ Dry matter (g/kg) } & \multicolumn{3}{|c|}{ Proportions in the forage $(\mathrm{g} / \mathrm{kg})$} \\
\hline & Leaves & Stem & Panicle & Plants & Leaves & Stem & Panicle \\
\hline & \multicolumn{7}{|c|}{ Oats } \\
\hline White & $195.5 b$ & 159.5b & $293.2 b$ & 198.0b & $314.8 \mathrm{a}$ & $386.2 b$ & $299.0 \mathrm{a}$ \\
\hline Black & $226.8 \mathrm{a}$ & $257.5 \mathrm{a}$ & $361.1 \mathrm{a}$ & $261.6 a$ & 211.6b & $633.1 \mathrm{a}$ & $155.3 b$ \\
\hline \multirow[t]{2}{*}{ Significance } & 0.0000 & 0.0015 & 0.0000 & 0.0033 & 0.0003 & 0.0000 & 0.0000 \\
\hline & \multicolumn{7}{|c|}{ Harvesting height } \\
\hline $10 \mathrm{~cm}$ & $213.2 \mathrm{a}$ & $201.9 a$ & $327.7 \mathrm{a}$ & $224.2 \mathrm{a}$ & $267.1 \mathrm{a}$ & $523.0 \mathrm{a}$ & $209.9 a$ \\
\hline $20 \mathrm{~cm}$ & 209.1a & $215.1 \mathrm{a}$ & $326.7 \mathrm{a}$ & $235.4 \mathrm{a}$ & 259.3a & $496.3 \mathrm{a}$ & $244.4 \mathrm{a}$ \\
\hline Significance & 0.5722 & 0.6088 & 0.8947 & 0.5495 & 0.7288 & 0.2245 & 0.1407 \\
\hline Means & 211.2 & 208.5 & 327.2 & 229.8 & 263.2 & 509.7 & 227.1 \\
\hline CV (\%) & 8.38 & 29.70 & 5.47 & 19.41 & 20.43 & 10.12 & 23.87 \\
\hline
\end{tabular}

Values followed by same letter in columns do not differ from each other by Tukey test at 5\% probability. 

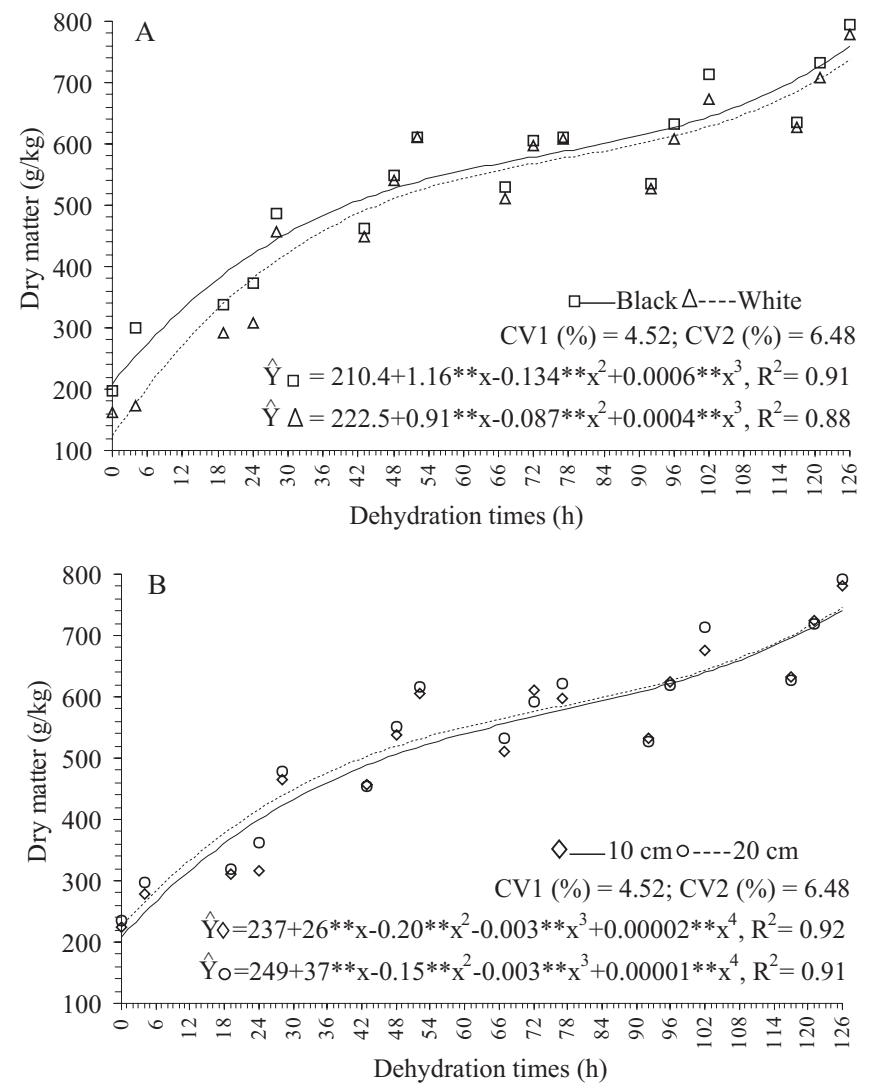

Figure 2 - Dehydration curves of white and black oats (A) at two cutting heights (B) in function of time of dehydration.

average values, with higher DM content for height of $20 \mathrm{~cm}$ (Table 4), possibly due to the reduced thickness of the material subjected to dehydration. With respect to oats, there was difference $(\mathrm{P}<0.05)$ between oats at $0,4,28$, and 102 hours after cutting. Higher DM content was observed in black oats at 0 and $4 \mathrm{~h}$; however, at 28 and $100 \mathrm{~h}$, the result was opposite (Table 4), suggesting there is less resistance to water loss in white oats, once despite having less content of DM in time of cutting, at the time of baling it equaled the black oat.

Differences in $\mathrm{CP}$ concentrations $(\mathrm{P}>0.05)$ were found between species of oats only at the time of cutting (Table 5), with white oats $(141.5 \mathrm{~g} / \mathrm{kg})$ superior to black oats $(118.5 \mathrm{~g} / \mathrm{kg})$. When comparing the periods of evaluation, the white oats presented higher levels of $\mathrm{CP}$ at the time of cutting and after storage, while the black oats presented higher CP content only at the time of baling. When comparing the heights of cutting in each evaluation period there was no significant difference $(\mathrm{P}<0.05)$; however, the $\mathrm{CP}$ values decreased at the time of baling in the time of cutting, and rose after storage. Similar CP levels were obtained in white oat hay $(129.0 \mathrm{~g} / \mathrm{kg}$ ) by Fukushima et al. (1999), while Floss et al. (2003) observed lower levels (83.5 g/kg) after 87 days of oat growth. Working with black oats, Moreira et al. (2005) found higher CP levels (190 and $130 \mathrm{~g} / \mathrm{kg}$ ) with the first cut (64 days of growth) and with regrowth (56 days of growth). The differences found in the literature are due to the different stages of crop development and use or non-fertilization. Variations in CP content with storage time are similar to those found by Nascimento et al. (2000) in alfalfa hay that had been sun-dried and stored for a period of 60 days.

Acid detergent fiber values were higher in black oats ( $\mathrm{P}>0.05$ ), with no differences found between cutting heights ( $\mathrm{P}>0.05)$ in all assessed periods (cutting, baling, and storage). The superiority of black oats is related to the lower leaf/stem ratio. Comparing the evaluation periods, $\mathrm{ADF}$ levels rose in black oats and with a cutting height of $20 \mathrm{~cm}$ at the time of baling and after storage, while there were no changes in the white oats or with a cutting height of $10 \mathrm{~cm}$ (Table 5). Floss et al. (2003) obtained an ADF content of $420 \mathrm{~g} / \mathrm{kg}$ after 103 days of oat growth. Changes in ADF levels with baling and storage are consistent with the results obtained by Neres et al. (2010), who also observed increased levels of ADF with baling and storage of alfalfa hay. However, in spite of the increased storage period, these ADF values lie within the recommended range for ruminants.

The NDF did not differ between species of oats and height of cutting studied ( $\mathrm{P}>0.05)$, but rose at the time of baling and after storage in relation to the cut $(\mathrm{P}<0.05)$ (Table 5). The values found are above those recommended for ruminants of 550-600 g/kg of feed (Mertens, 1994). Fukushima et al. (1999) studied different componentsof the diet of sheep and found lower levels of NDF $(570 \mathrm{~g} / \mathrm{kg})$ in oat hay, while Floss et al. (2003) found an NDF content of $620 \mathrm{~g} / \mathrm{kg}$ in oats with 103 days of growth. These differences are primarily related to climatic conditions and stages of plant development.

With regard to hemicellulose, a higher content was observed in black oats at the time of cutting $(\mathrm{P}<0.05)$ and in baled white oats $(\mathrm{P}<0.05)$, with no differences after storage or between cutting heights in all periods of evaluation $(\mathrm{P}>0.05)$. When comparisons between periods were carried out, a lower hemicellulose content was found in white oats with $10 \mathrm{~cm}$ cutting height at the time of cutting and a higher hemicellulose content was found in black oat with a $20 \mathrm{~cm}$ cutting height after storage (Table 5).

Cellulose is a major constituent of cell walls (Van Soest, 1994), and in this experiment it was present in greater quantities in black oats at all times $(\mathrm{P}<0.05)$ and in the material obtained with a height of $10 \mathrm{~cm}$ at the time of cut $(\mathrm{P}<0.05)$. Over the evaluation period, a significant increase was observed in levels of cellulose of the cut for baling only to black oats (Table 5). The values found are consistent with those described in the literature, because according to Van 
Table 4 - Dry matter content ( $\mathrm{g} / \mathrm{kg}$ ) of black and white oats under two cutting heights at the time of the cut (0 h), baling (126 h), and the time corresponding to the time of $17 \mathrm{~h}$ each day of the period of dehydration

\begin{tabular}{|c|c|c|c|c|c|c|c|c|c|c|}
\hline & \multicolumn{7}{|c|}{ Dehydration times (h) } & \multirow[t]{2}{*}{ Mean } & \multirow{2}{*}{$\begin{array}{l}\text { CV1 } \\
(\%) \\
\end{array}$} & \multirow[t]{2}{*}{ Significance } \\
\hline & 0 & 4 & 28 & 52 & 77 & 102 & 126 & & & \\
\hline $\begin{array}{l}\text { White } \\
\text { Black }\end{array}$ & $\begin{array}{l}198.0 \mathrm{~b} \\
261.6 \mathrm{a}\end{array}$ & $\begin{array}{l}303.6 \mathrm{~b} \\
272.7 \mathrm{a}\end{array}$ & $\begin{array}{l}485.6 \mathrm{a} \\
457.2 \mathrm{~b}\end{array}$ & $\begin{array}{l}610.0 \mathrm{a} \\
612.0 \mathrm{a}\end{array}$ & $\begin{array}{l}610.9 \mathrm{a} \\
609.1 \mathrm{a}\end{array}$ & $\begin{array}{l}713.2 \mathrm{a} \\
674.1 \mathrm{~b}\end{array}$ & $\begin{array}{l}794.7 \mathrm{a} \\
779.7 \mathrm{a}\end{array}$ & $\begin{array}{l}530.8 \mathrm{a} \\
523.8 \mathrm{a}\end{array}$ & \multirow[t]{2}{*}{1.15} & $\begin{array}{c}\text { Oat*Time } \\
0.0000\end{array}$ \\
\hline \multicolumn{9}{|c|}{ Harvesting height } & & Height*Time \\
\hline $\begin{array}{l}10 \mathrm{~cm} \\
20 \mathrm{~cm} \\
\mathrm{CV} 2(\%)\end{array}$ & $\begin{array}{l}224.2 \mathrm{a} \\
235.4 \mathrm{a}\end{array}$ & $\begin{array}{l}279.3 a \\
297.0 a\end{array}$ & $\begin{array}{l}465.1 \mathrm{a} \\
477.6 \mathrm{a}\end{array}$ & $\begin{array}{c}605.4 \mathrm{a} \\
616.6 \mathrm{a} \\
6.28\end{array}$ & $\begin{array}{l}598.3 a \\
621.7 a\end{array}$ & $\begin{array}{l}674.5 \mathrm{a} \\
712.8 \mathrm{a}\end{array}$ & $\begin{array}{l}782.2 \mathrm{a} \\
792.2 \mathrm{a}\end{array}$ & $\begin{array}{l}518.4 \mathrm{~b} \\
536.2 \mathrm{a}\end{array}$ & 1.15 & 0.7527 \\
\hline
\end{tabular}

Means followed by different letters in the column for each source of variation differ by Tukey test at $5 \%$ probability.

Soest (1994) cellulose content can vary from 200 to $400 \mathrm{~g} / \mathrm{kg}$. The higher content of cellulose observed in black oats is related to the levels of ADF and lignin, which were also higher in this forage, as according to Van Soest (1994) several factors can inhibit the digestibility of cellulose, such as lignin, silica, cutin, and intrinsic properties of the cellulose itself.

The lignin content was lower in white oats at all time points $(\mathrm{P}<0.05)$, with no difference according to cutting height ( $\mathrm{P}>0.05$ ) (Table 5). For periods of dehydration, an increase in lignin content was observed in both types of oats from the time of cutting to the end of the storage period. For the cutting height of $20 \mathrm{~cm}$, an increase in lignin was observed during baling and storage. Moreira et al. (2005) observed an average lignin content of $52 \mathrm{~g} / \mathrm{kg}$ after 64 days of oat growth. Their study is important because lignin is one of the three compounds that bind to form the fiber fraction of forages, which is considered the main factor limiting the digestibility (Van Soest, 1994), and their excess may cause a reduction in consumption (Rogerio et al., 2007).

As for the ADIP contents, there were no significant differences between oats in the evaluation periods $(\mathrm{P}<0.05)$, while for the cutting height, $20 \mathrm{~cm}$ allowed less ADIP content. In the case of the assessment periods a reduction in levels of ADIP of the cut for storage was observed only with a cutting height of $10 \mathrm{~cm}$ (Table 5). For NDIP contents, no differences were observed between the oats and cutting heights in any of the periods $(\mathrm{P}<0.05)$, and only for black oats there was a reduction in the NDIP levels of the material observed after cutting and storage. Neres et al. (2010), studying alfalfa hay, observed the opposite pattern for the $\mathrm{CP}$ remaining in the residue of NDF or ADF, although the authors adopted a storage period three times longer than that used in this study.

The quantification of CP associated with NDF and ADF (NDIP and ADIP) is important in the study of CP degradability of hay as well as the proportion of CP in relation to the total and the possible relationship of these components with the digestibility of nutrients and consumption of these forages (Aguiar et al., 2006). Likewise, the study of NDF components is critical, because the components of the NDF cannot be considered homogeneous nutritional entities (Van Soest, 1994), as well as CP, and if they are, they can lead to distortions in estimates of the apparently digestible fraction from the chemical composition of feeds produced in tropical conditions (Detman et al., 2008).

According to Silva \& Queiroz (2006), both ADIP and NDIP may be present naturally in plants or may be considered an indicator of the damage caused by heat. Since there were no large variations in the levels of these components (Table 5) it is evident that the method used for the dehydration of forage was adequate (Nascimento et al., 2000). Based on the results, it can still be inferred that the DM content of forages at the time of baling did not cause an increase in bale temperature during storage, since, according to Van Soest (1994), increases occur when the humidity is high and the temperature reaches values above $55^{\circ} \mathrm{C}$. The estimate of the ADIP fraction in particular becomes relevant due to its use as a predictor or estimator of potential protein use for not being available to microorganisms in the rumen or intestine (Clipes et al., 2010). Aguiar et al. (2006), studying the NDIP of tropical grass hays, found values ranging from 454.5 to $546.6 \mathrm{~g} / \mathrm{kg}$, while Gobbi et al. (2005), studying the hay Brachiaria decumbens Stapf., found $488 \mathrm{~g} / \mathrm{kg}$ of total $\mathrm{N}$ bound to the cell wall and $248 \mathrm{~g} / \mathrm{kg}$ of $\mathrm{N}$ connected to the ADF.

In relation to the occurrence of fungi, there was effect $(\mathrm{P}<0.05)$ on the populations of Aspergillus and Penicillium and on the total population of fungi from the evaluation period,cutting height and evaluation period $\times$ height interaction. Larger population of Aspergillus was observed 
Table 5 - Chemical composition of white and black oat hay under two cutting heights at the time of cutting, baling and after 30 days of storage

\begin{tabular}{|c|c|c|c|c|c|c|c|c|}
\hline & Harvesting & Balling & Storage & Mean & Harvesting & Balling & Storage & Mean \\
\hline Black & $118.5 \mathrm{Bb}$ & 118.6Ba & 149.8Aa & $129.0 \mathrm{a}$ & $408.2 \mathrm{Ba}$ & 479.5Аа & 456.5А А & $448.1 \mathrm{a}$ \\
\hline \multicolumn{9}{|c|}{ Harvesting height } \\
\hline $20 \mathrm{~cm}$ & $133.0 \mathrm{Ba}$ & $118.3 \mathrm{Ca}$ & $146.1 \mathrm{Aa}$ & $132.5 \mathrm{a}$ & 383.9Bа & $436.3 \mathrm{Aa}$ & $429.2 \mathrm{Aa}$ & $416.5 \mathrm{a}$ \\
\hline Mean & \multirow{2}{*}{\multicolumn{4}{|c|}{9.65}} & $394.4 B$ & $434.7 \mathrm{~A}$ & $431.1 \mathrm{~A}$ & \\
\hline CV1 (\%) & & & & & \multicolumn{4}{|c|}{9.06} \\
\hline \multirow[t]{2}{*}{ CV2 (\%) } & \multicolumn{4}{|c|}{14.27} & \multicolumn{4}{|c|}{8.56} \\
\hline & \multicolumn{4}{|c|}{ NDF $(g / k g)$} & \multicolumn{4}{|c|}{ Hemicellulose (g/kg) } \\
\hline $10 \mathrm{~cm}$ & 686.9Ba & 754.9Aа & 766.9Aa & $73.62 \mathrm{a}$ & $282.0 \mathrm{Ba}$ & $321.7 \mathrm{Aa}$ & $334.0 \mathrm{Aa}$ & $312.6 \mathrm{a}$ \\
\hline $20 \mathrm{~cm}$ & $672.2 \mathrm{Ba}$ & 749.7Aa & 773.8Aa & 73.19a & 288.3Ва & $313.5 \mathrm{ABa}$ & 344.6Аа & $315.5 \mathrm{a}$ \\
\hline Mean & $679.6 \mathrm{~B}$ & $752.3 \mathrm{~A}$ & $770.3 \mathrm{~A}$ & & $285.2 \mathrm{~B}$ & $317.6 \mathrm{~A}$ & $339.3 \mathrm{~A}$ & \\
\hline CV1 (\%) & \multirow{2}{*}{\multicolumn{4}{|c|}{$\begin{array}{l}6.29 \\
7.92\end{array}$}} & \multicolumn{4}{|c|}{14.00} \\
\hline \multirow[t]{3}{*}{ CV2 (\%) } & & & & & & & & \\
\hline & \multicolumn{4}{|c|}{ Cellulose (g/kg) } & \multicolumn{4}{|c|}{ Lignin (g/kg) } \\
\hline & \multicolumn{7}{|c|}{ Oats } & \\
\hline White & 291.9Ab & $302.3 \mathrm{Ab}$ & $304.2 \mathrm{Ab}$ & $299.5 b$ & $35.3 \mathrm{Bb}$ & $45.1 \mathrm{ABb}$ & $55.5 \mathrm{Ab}$ & $45.3 b$ \\
\hline Black & $321.5 \mathrm{Ba}$ & $338.4 \mathrm{ABa}$ & 348.6Аa & $336.2 \mathrm{a}$ & $56.1 \mathrm{Ba}$ & 78.0Aa & $71.0 \mathrm{Aa}$ & $68.3 a$ \\
\hline & & & & & & & & \\
\hline White & $284.6 \mathrm{Aa}$ & $283.0 \mathrm{Aa}$ & $242.4 \mathrm{Aa}$ & $270.0 \mathrm{a}$ & 425.6Aa & 395.3Аа & 462.7Аa & $427.9 \mathrm{a}$ \\
\hline Black & $308.9 \mathrm{Aa}$ & $291.0 \mathrm{Aa}$ & $288.7 \mathrm{Aa}$ & $296.2 \mathrm{a}$ & $483.8 \mathrm{Aa}$ & $401.5 \mathrm{ABa}$ & $396.3 \mathrm{Ba}$ & $427.2 \mathrm{a}$ \\
\hline & & & & Harve & ght & & & \\
\hline $10 \mathrm{~cm}$ & $328.7 \mathrm{Aa}$ & $292.8 \mathrm{ABa}$ & $263.5 \mathrm{Ba}$ & $295.0 \mathrm{a}$ & 476.6Aa & $382.2 \mathrm{Ba}$ & 458.9ABa & $439.2 \mathrm{a}$ \\
\hline $20 \mathrm{~cm}$ & $264.8 \mathrm{Ab}$ & $281.2 \mathrm{Aa}$ & 267.7Aa & $271.2 \mathrm{a}$ & $432.7 \mathrm{Aa}$ & 414.6Aa & $400.1 \mathrm{Aa}$ & $415.8 \mathrm{a}$ \\
\hline Mean & $296.8 \mathrm{~A}$ & $287.0 \mathrm{~A}$ & $265.6 \mathrm{~A}$ & & $454.7 \mathrm{~A}$ & $398.4 \mathrm{~A}$ & $429.5 \mathrm{~A}$ & \\
\hline CV1 (\%) & & & & & & & & \\
\hline CV2 (\%) & & & & & & & & \\
\hline
\end{tabular}

${ }^{1}$ Values expressed in $\mathrm{g} / \mathrm{kg}$ crude protein.

* Values followed by same uppercase and lowercase in the row in the column do not differ by Tukey test at $5 \%$.

CV (\%) - coefficient of variation; CP - crude protein; NDF - neutral detergent fiber; ADF - acid detergent fiber; NDIP - neutral detergent insoluble protein; ADIP - acid detergent insoluble protein.

after storage, when a cutting height of $10 \mathrm{~cm}$ led to greater development of this fungus (Figure 3). This result may be related to the proximity of the soil material in the production of hay cut at $10 \mathrm{~cm}$ from the soil, allowing a greater number of granules of soil to come into contact with the plants, affecting the population of fungi.
Regarding storage, according to Reis et al. (1997), an increase in fungi of the genus Aspergillus is related to the moisture content of the hay. Storage fungi such as Aspergillus can serve as a biological indicator of the conditions of storage and their quantification in conserved forages is essential as they represent a potent producer of 

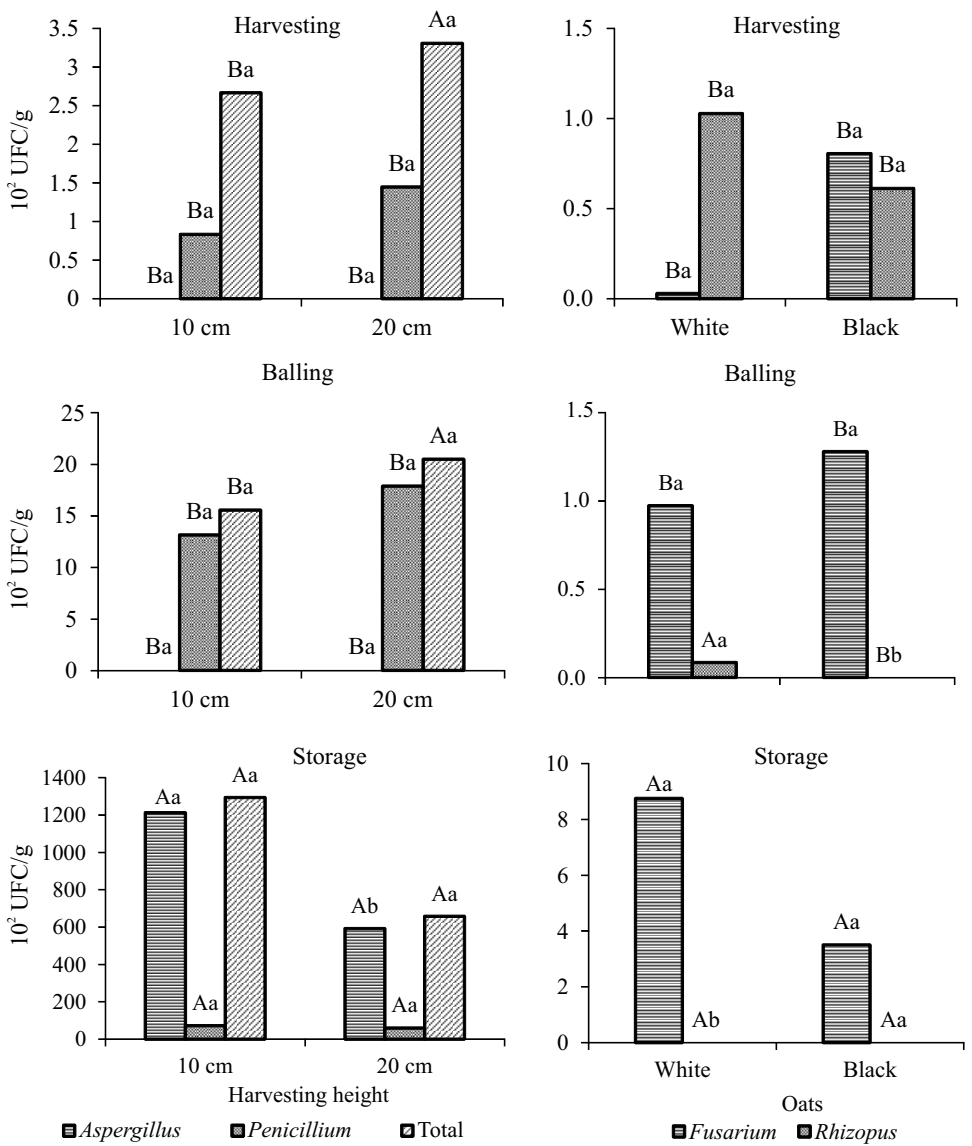

Bars followed by the same uppercase and lowercase letters for each fungus for each evaluation period did not differ by the Tukey test at $5 \%$ probability.

Figure 3 - Occurrence of fungi of the genera Aspergillus, Penicillium and total and fungi of the genera Fusarium and Rhizopus and white oat hay under two cutting heights at the time of cutting, baling and after 30 days of storage (original data).

mycotoxins (Moser, 1995), which occur more frequently in hot and humid environments. The population of Cladosporium was not affected by the factors studied $(\mathrm{P}>0.05)$ and remained constant with an average value of $1 \times 10^{2} \mathrm{CFU} / \mathrm{g}$. With regard to the populations of Fusarium and Rhizopus, the evaluation period, the oat species, and the evaluation period $\times$ oats interaction had no significant effect $(\mathrm{P}<0.05)$. The largest populations of both fungi were observed in the hay after storage, while the white oats favored population growth of Rhizopus at the time of baling and after storage (Figure 3 ).

The diverse population of fungi observed in this study is related to the drying process, since, according to Gregory (1963), during drying there is an opportunity for the occurrence of a very diverse population of microorganisms, which live in the air, plants, and soil, and this diversity of propagules suggests that different types of microflora may develop later, according to the conditions prevailing in the bales in any period.

\section{Conclusions}

The cutting management interferes with the production of dry matter of oats and production of postharvest waste. The hay obtained by cutting the black and white oats at heights of 10 and $20 \mathrm{~cm}$ showed similar dehydration curves, and reached similar levels of DM at the end of 124 hours of dehydration. The white oat hay provides the best nutritional value with lower levels of cellulose, ADF, and lignin. White oats are the most suitable for hay production with cutting heights of 10 and $20 \mathrm{~cm}$. The storage of white and black oat hay promoted an increase in the population of fungi of the genera Aspergillus and Penicillium.

\section{References}

AGUIAR, E.M.; COSTA LIMA, G.F.; SANTOS, M.V.F. et al. Rendimento e composição químico-bromatológica de fenos triturados de gramíneas tropicais. Revista Brasileira de Zootecnia, v.35, n.6, p.2226-2233, 2006 
ASSOCIATION OF OFFICIAL ANALYTICAL CHEMISTS - AOAC. Official methods of analysis. 15.ed. Virginia: Arlington. 1990. 1117p.

BARNETT, H.L.; HUNTER, B.B. Illustrated genera of imperfect fungi. New York: Macmillan Publishing Company, 1987. 218p.

BORTOLINI, P.C.; MORAES, A.; CARVALHO, P.C.F. Produção de forragem e de grãos de aveia branca sob pastejo. Revista Brasileira de Zootecnia, v.34, n.6, p.2192-2199. 2005.

CAMARGO, R.; PIZA, R.J. Produção de biomassa de plantas de cobertura e efeitos na cultura do milho sob sistema plantio direto no município de Passos, MG. Bioscience Journal, v.23, n.3, p.76-80, 2007.

CARMICHAEL, J.W.; KENDRICK, W.B.; CONNERS, I.L. et al. Genera of Hyphomycetes. Manitoba: Hignell Printing, 1980. 386p.

CASTAGNARA, D.D.; RADIS, A.C.; SOUZA, L.C. et al. Características estruturais e produtivas da aveia preta Comum em cinco idades de rebrota na região Oeste do Paraná. Cultivando o Saber, v.3, n.2, p.116-129, 2010.

CERETTA, C.A.; BASSO, C.J.; HERBES, M.G. et al. Produção e decomposição de fitomassa de plantas invernais de cobertura de solo e milho, sob diferentes manejos da adubação nitrogenada. Ciência Rural, v.32, p.49-54, 2002.

CLIPES, R.; DA SILVA, J.; DETMANN, E. et al. Proteína insolúvel em detergente ácido como estimador da fração protéica não degradável no rúmen de forragens tropicais. Revista Brasileira de Saúde e Produção Animal, v.11, n.2, p.463-473, 2010.

COLLINS, C.A. Hay preservation effects on yield and quality. In:. MOORE, K.J.; KRAL, D.M.; VINEY, M.K. (Eds). Post-harvest physiology and preservation of forages. Madison: American Society of Agronomy, 1995. p.67-90.

COMISSÃO BRASILEIRA DE PESQUISA DE AVEIA - CBPA. Indicações técnicas para a cultura da aveia. Guarapuava: Fundação Agrária de Pesquisa Agropecuária, 2006. 82p.

CONFORTIN, A.C.C.; ROCHA, M.G.; QUADROS, F.L.F. et al. Structural and morphogenical characteristics of black oats and Italian ryegrass on pasture submitted to two grazing intensities. Revista Brasileira de Zootecnia, v.39, n.11, p.2357-2365, 2010.

DETMANN, E.; MAGALHÃES, K.A.; VALADARES FILHO, S.C. et al. Desenvolvimento de um submodelo bicompartimental para estimação da fração digestível da proteína bruta em bovinos a partir da composição química dos alimentos. Revista Brasileira de Zootecnia, v.37, n.12, p.2215-2221, 2008.

DOMINGUES, J.L. Uso de volumosos conservados na alimentação de eqüinos. Revista Brasileira de Zootecnia, v.38, supl., p.259-269, 2009.

EMPRESA BRASILEIRA DE PESQUISA AGROPECUÁRIA EMBRAPA. Sistema Brasileiro de Classificação de Solos. Brasília, 2006. p.412.

FERNANDEZ, M.R. Manual para laboratório de fitopatologia. Passo Fundo: EMBRAPA-CNPT, 1993. 128p.

FERRARI JÚNIOR, E.; RODRIGUES, L.R.A.; REIS, R.A. et al. Avaliação do capim Coastcross para a produção de feno em diferentes idades e níveis de adubação de reposição. Boletim Indústria Animal, v.50, n.2, p.137-145, 1993.

FLOSS, E.L. Aveia, um sustentáculo do sistema de semeadura direta. Revista Plantio Direto, v.72, p.14-18, 2002.

FLOSS, E.L.; BOIN, C.; PALHANO, A.L. et al. Efeito do estádio de maturação sobre o rendimento e valor nutritivo da aveia branca no momento da ensilagem. Boletim da Indústria Animal, v.60, n.2, p.117-126, 2003.

FLOSS, E.L.; PALHANO, A.L.; SOARES FILHO, C.V. et al. Crescimento, produtividade, caracterização e composição química da aveia branca. Acta Scientiarum Animal Science, v.29, n.1, p.1-7, 2007.

FONTANELI, R.S.; SANTOS, H.P.; FONTANELI, R.S. Forrageiras para integração lavoura-pecuária-floresta na região sulbrasileira. Passo Fundo: Embrapa Trigo, 2009. 340p.
FUKUSHIMA, R.S.; ROSA, A.J.M.; LIMA, C.G. et al. Comparação entre dois métodos analíticos para determinação da lignina de algumas gramíneas forrageiras. Pesquisa Agropecuária Brasileira, v.34, n.6, p.1024-1030, 1999.

GIACOMINI, S.J.; AITA, C.; HÜBNER, A.P. et al. Liberação de fósforo e potássio durante a decomposição de resíduos culturais em plantio direto. Pesquisa Agropecuária Brasileira, v.38, n.9, p.1097-1104, 2003.

GOBBI, K.F.; GARCIA, R.; PEREIRA, O.G. et al. Composição química e digestibilidade in vitro do feno de Brachiaria decumbens Stapf. Tratado com uréia. Revista Brasileira Zootecnia, v.34, p.720-725, 2005.

GREGORY, P.H. Microbial and biochemical changes during the moulding of hay. Journal of Genetic Microbiology, v.33, p.147-174, 1963.

INSTITUTO AGRONÔMICO DO PARANÁ - IAPAR. [2006] Cartas climáticas do Paraná. Available at: <http://200.201.27.14/ Site/Sma/Cartas_Climaticas/Classificação_Climaticas.htm> Accessed on: Sept. 3, 2008.

JOBIM, C.C.; NUSSIO, L.G.; REIS, R.A. et al. Avanços metodológicos na avaliação da qualidade da forragem conservada. Revista Brasileira de Zootecnia, v.36, p.101-119, 2007 (supl.).

JOBIM, C.C.; LOMBARD, L.; GONÇALVES, G.D. et al. Desidratação de cultivares de Cynodon spp. durante o processo de fenação. Acta Scientiarum, v.23, n.4, p.795-799, 2001.

LANZANOVA, M. E.; NICOLOSO, R.S.; LOVATO, T. et al. Atributos físicos do solo em sistema de integração lavoura-pecuária sob plantio direto. Revista Brasileira de Ciência do Solo, v.31, n.5, p.1131-1140, 2007.

LOPES, M.L.; CARVALHO, P.C.F.; ANGHINONI, I. et al. Sistema de integração lavoura-pecuária: efeito do manejo da altura em pastagem de aveia preta e azevém anual sobre o rendimento da cultura da soja. Ciência Rural, v.39, n.5, p.1499-1506, 2009.

MARTINS, C.E.N.; QUADROS, F.L.F.; BANDINELLI, D.G. et al. Densidade de forragem nos estratos verticais de uma pastagem de aveia e azevem submetida a diferentes niveis de biomassa de lamina foliar verde. In: REUNION DEL GRUPO TECNICO REGIONAL DEL CONO SUR EM MEJORAMENTO Y UTILIZACION DE LOS RECURSOS FORRAJEROS DEL AREA TROPICAL Y SUBTROPICAL - Grupo Campos. Anais... Salto, Uruguai: Universidad de la Replubica, 2004. p.20-24.

MERTENS, D.R. Regulation of forage intake. In: FAHEY JR., G.R. (Ed.) Forage quality, evaluation and utilization. Madison: American Society of Agronomy, 1994. p.450-493.

MOREIRA, A.L.; RUGGIERI, A.C.; REIS, R.A. et al. Avaliação da aveia preta e de genótipos de aveia amarela para produção de forragem. ARS Veterinaria, v.21, Suplemento, p.175-182, 2005.

MOSER, L.E. Post-harvest physiological changes in forage plants. In: MOORE, K.J.; KRAL, D.M.; VINEY, M.K. (Eds.) Postharvest physiology and preservation of forages. Madison: American Society of Agronomy Inc., 1995. p.1-19.

NASCIMENTO, J.M.; COSTA, C.; SILVEIRA, A.C. Influência do método de fenação e tempo de armazenamento sobre a composição bromatológica e ocorrência de fungos no feno de alfafa (Medicago sativa, L. cv. Flórida 77). Revista Brasileira de Zootecnia, v.29 n.3, p.669-677, 2000.

NERES, M.A.; CASTAGNARA, D.D.; MESQUITA, E.E. et al. Production of alfalfa hay under different drying methods. Revista Brasileira de Zootecnia, v.39, n.8, p.1676-1683, 2010.

PINTO, M.S.C.; ANDRADE, M.V.M.; SILVA, D.S. et al. Curva de desidratação da maniçoba (Manihot pseudoglaziovii) durante o processo de fenação. Archivos de Zootecnia, v.55, n.212, p.389-392, 2006.

PRIMAVESI, O.; PRIMAVESI, A.C.; ARMELIN, M.J.A. Qualidade mineral e degradabilidade potencial de adubos verdes conduzidos sobre Latossolos, na região tropical de São Carlos, SP, Brasil. Revista de Agricultura, v.77, p.89-102, 2002. 
REIS, R.A.; PANIZZI, R.C.; ROSA, B. Efeito da amonização sobre a ocorrência de fungos, composição química e digestibilidade in vitro de fenos de grama seda (Cynodon dactylon (L.) Pers). Revista Brasileira de Zootecnia, v.26, n.3, p.454-460, 1997.

REIS, R.A.; SOLLENBERGER, L.E.; URBANO, D. Impacto of overseeding cool-season annual forages on spring regrowth of Tifton 85 bermudagrass. In: international grassland congress, 19., 2001, São Pedro. Proceedings... São Pedro: Brazilian Society of Animal Husbandry, 2001. p. 295-297.

ROGÉRIO, M.C.P.; BORGES, I.; NEIVA, J.N.M. et al. Valor nutritivo do resíduo da indústria processadora de abacaxi (Ananas comosus L.) em dietas para ovinos. 1. Consumo, digestibilidade aparente e balanços energético e nitrogenado. Arquivo Brasileiro Medicina Veterinária e Zootecnia, v.59, p.773-781, 2007.

ROSSETTO, C.; NAKAGAWA, J. Época de colheita e desenvolvimento vegetativo de aveia preta. Scientia Agrícola, v.58, n.4, p.731-736, 2001.
ROTZ, C.A. Field curing of forage. In: MOORE, K.J.; KRAL, D.M.; VINEY, M.K. (Eds.) Post-harvest physiology and preservation of forages. Madison: American Society of Agronomy Inc., 1995. p.39-66.

SÁ, J.C.M.; VIEIRA, A.M.; BOZZA, D.L. et al. Avaliação do desenvolvimento radicular e atributos de genótipos de milho submetidos a níveis de palha no sistema plantio direto. Revista Plantio Direto, v.80, p.46-60, 2004.

SCHUCH, L.O.B.; NEDEL, J.L.; ASSIS, F.N. et al. Vigor de sementes e análise do crescimento de aveia preta. Scientia Agricola, v.57, n.2, p.305-312, 2000.

SILVA, D.J.; QUEIROZ, A.C. Análise de alimentos: métodos químicos e biológicos. Viçosa, MG: UFV, 2006. 235p.

VAN SOEST, P.J. Nutritional ecology of the ruminant. Ithaca: Constock Publishing Associates, 1994. 476p.

VAN SOEST, P.J.; ROBERTSON, J.B.; LEWIS, B.A. Methods for dietary fiber, neutral detergent fiber and non starch polysaccharides in relation to animal nutrition. Journal of Dairy Science, v.74, 3583-3597, 1991. 